\title{
The Effect of Organizational Citizenship Behavior (OCB) and Quality of Work Life (QWL) on The Employee Work Performance with Motivation As An Intervening Variables at Industrial affairs Of South Sumatera Province
}

\author{
Agustina Hanafi $^{1}$, Bambang Bemby Soebyakto ${ }^{2}$, Meldha Afriyanti ${ }^{3}$ \\ Magister of Management Science, Faculty of Economics, Sriwijaya University
}

\begin{abstract}
Organizational Citizenship Behavior (OCB) is a new concept in terms of performance analysis that is not regulated by the organization, and a formal reward system is not taken into account, but this behavior will encourage the effectiveness and efficiency of the overall organizational function. High employee performance will also be created when Quality of Work Life (QWL) provides comfort and prosperity in the work environment, because it is consideredbe able to increase the role and contribution of employees in an organization. High work motivation will also have an impact on the better performance given by employees to achieve the goals of the institution. The purpose of this research are to find out whether or not : OCB affects work motivation, QWL affects work motivation, OCB affects employee performance, QWL affects employee performance, Work motivation affects employee performance, The effect of work motivation as a mediation of OCB to employee performance, The effect of work motivation as a mediation of the QWL to work performance.
\end{abstract}

Keywords: OCB, QWL, work motivation, work performance

\section{Introduction}

In responding on local government regulations changes mandated by Act Number 23 of 2014 and stipulated Government Regulation (PP) Number 18 of 2016 concerning regional apparatus, the government of South Sumatra Province carries out changes in regional apparatus (nomenclature), so that there are several the impact on separating or mergering some departments and affairs and there arealso several agencies changed their names. The changes in regional apparatus (nomenclature) in the government of South Sumatra Province transform 19 services into 29 services agencies. The same thing also happened in the Office of Industry and Trade services and Cooperation (Perindagkop) which is now divided into three, namely the Cooperation services and Small and Medium Enterprises (SMEs), the Trade Services and the Industrial affairs. The Industrial affair of South Sumatra Province after the changes conducted becomes one of the government agencies that servesin the industrial sector. Where guidance, supervision and industrial development are directed to develop the industrial sector of South Sumatra Province in facing global competition. Therefore, the South Sumatra Provincial Industrial affairs needs to accommodate competent State Civil Servants (ASN) in providing services to the public, and be able to improve coordination in developing the industry in South Sumatra Province. Through the vision of the agency is "the realization of advanced and globally competitive Industry in the South Sumatra ". It shows that the government of South Sumatra Province hopes to provide the best service to meet the needs and satisfy the interests of people, so that indirectly this requires the State Civil Service (ASN) as a public servant be able to show good work performance.

Therefore, it is important to implementthe Organizational Citizenship Behavior (OCB) behavior in improving employee performance in these agencies. According to Borman and Motowidlo (1993) states that Organizational Citizenship Behavior (OCB) can improve 
performance because this behavior is "lubricant" of social machines in an organization. In other words, the existence of this behavior will lead to motivation among employees at work, so that it can make social interactions among employees become smooth, reduce the occurrence of disputes and improve efficiency, and ultimately it can improve the employeesperformance.

In addition to Organizational Citizenship Behavior (OCB), Quality Of Work Life (QWL) on employees also need to be concerned by leadership in an effort to support the achievement of highperformance of the employees by meeting the needs and expectations of the employees. The Quality Of Work Life (QWL) is a major problem that deserves to be concerned in an organization (Lewis, 2001), It refers to the idea that the quality of work life is seen as capable of enhancing organizational participation.

Work motivation is also very influential on employee performance. According to Hasibuan (2012) states that giving motivation to employees can generate enthusiasm and morale, improve morale and satisfaction, increase employee work productivity, maintain employee loyalty and stability, and increase discipline and reduce employee attendance. It shows that the greater the motivation given to employees, the more employees will give a good reciprocity to the organization in form of better performance given to the organization.

\section{Literarure Review \\ Organizational Citizenship Behavior (OCB)}

Organizational Citizenship Behavior (OCB) is a new concept in terms of performance analysis. According to Organ in Podsakoff (2009) that: Organizational Citizenship Behavior (OCB) is carried out by an individual with full freedom (at will) in determining something and mutual understanding with no request for formal rewards or rewards for the organization, so this behavior is very helpful and profitable because this behavior increases efficiency and effectiveness in the organization. Meanwhile, according to Spitzmuller, Van Dyne and Ilies in Gunawan (2013) OCB is an individual behavior that is not regulated by the organization, and that the reward system is not formally calculated, but this behavior will encourage the effectiveness and efficiency of the overall organizational function.

\section{Quality Of Work Life (QWL)}

The Quailty of Work Life is one of the management system approaches to coordinate and connect the potential of Human Resources (HR), where the quality of work life in the organization as a leadership effort to meet the needs of members and organizations on an ongoing basis. Where according to Cascio (2010), that Quality of Work Life (QWL) can be interpreted into two approaches, the first, Quality of Work Life (QWL) is a set of goals to be achieved through organizational policies such as: safe working conditions, internal promotion policies, work involvement, fair compensation and others. While the second approach defines the Quality of Work Life (QWL) as employees' perceptions such as that employees feel safe at work, relatively satisfied and get the opportunity to grow and develop as human beings.

\section{Work motivation}

Motivation is defined as a driving force or impulse to humans that can lead to, direct, and organize behavior (Darmawan, 2013). The understanding of motivation is inseparable from the word needs or wants. Needs are a potential within human beings that needs to be responded to, because motivation is the reason of an individual or employee to act in meeting their needs. According to (Luthans, 2011) motivation comes from the Latin word movere, which means to move, in other words motivation is a process that starts with physiological deficiencies or psychological that drives the behavior shown for the purpose or incentive.

\section{Work Performance}

According to Kusnadi (2003) states that performance is a movement or action carried out consciously which is directed to achieve a certain goal or target. The understanding of performance is also an illustration of achievement level of the implementation of an activity program or policy in realizing the goals, objectives, vision, and mission of the organization as outlined in an organization's strategic planning. According to Mathis and Jackson (2009) performance is what is done or not to be done by employees, and also performance can be interpreted as the result of work that has a strong relationship with the organization's strategic goals, customer satisfaction, and contributes to the economy. Information about organizational performance is a very important thing to evaluate whether the performance process carried out by the organization has been in line with the expected goals or not.

\section{The objective of the study}


a. To find out and analyze the effect of Organization Citizenship Behavior (OCB) and Quality of Work Life (QWL) on the performance of employees at the Industrial affair of South Sumatra Province.

b. To find out and analyze the effect of Organization Citizenship Behavior (OCB) and Quality of Work Life (QWL) on the performance of employees with work motivation as an intervening variable at Industrial affair of South Sumatra Province.

\section{Methodology}

\section{Scope of study}

This study analyzes the relationship between Organization Citizenship Behavior (OCB) and Quality of Work Life (QWL) on the performance of employees with work motivation as an intervening variable at Industrial affair of South Sumatra Province. The location of research object is at Jalan Demang Lebar Daun No. 2610 Palembang, and the study was conducted in February 2018.

\section{Types and Data Sources}

In this study the data used in form of quantitative data, which includes data on the number of employees in Industrial affair of South Sumatra Province and the results of data processing from the research questionnaire. The data source in this study used primary data, where primary data collection was carried out by distributing questionnaires to employees at Industry affairs of South Sumatra Province.

\section{Population and Sample}

The population in this study was employees at Industry affairs of South Sumatra Province, there were 71 people, in which the census method was used by giving questionnaires to the entire population totaling 71 respondents consisting of permanent employees and non-permanent (honorary) employees at the Office of Industrial affair South Sumatera Province.

\section{Method of collecting data}

The method used to collect data in this study was observation, which is collecting data by conducting direct observations, and recording phenomena that occur at the location of the study, such as observing employee behavior about the time of arrival at work, work atmosphere and employee attitudes in carrying out tasks and job. In addition, data collection was carried out by distributing questionnaires about Organizational Citizenship
Behavior (OCB), Quality Of Work Life (QWL), work motivation (WM) and work performance (WP) at the office of Industry affairs of South Sumatra Province to all respondents with the aim of collecting answer to be the data this research.

\section{Result and Discussion}

\subsection{Result}

\section{a. Linearity Test}

The linearity test can be seen from the Sig. Linearity if Sig $<0.05$, the regression model is linear and vice versa.

\section{Table 1 Linearity Test Results}

\begin{tabular}{|c|c|c|c|}
\hline $\begin{array}{c}\text { Independent } \\
\text { Variable }\end{array}$ & $\begin{array}{c}\text { Dependent } \\
\text { Variables }\end{array}$ & $\begin{array}{c}\text { Sig. } \\
\text { Linearity }\end{array}$ & Note \\
\hline$O C B$ & $\mathrm{WM}$ & 0.000 & Linear \\
\hline$Q W L$ & $\mathrm{WM}$ & 0.000 & Linear \\
\hline$O C B$ & $\mathrm{WP}$ & 0.000 & Linear \\
\hline$Q W L$ & $\mathrm{WP}$ & 0.000 & Linear \\
\hline $\mathrm{WM}$ & $\mathrm{WP}$ & 0.000 & Linear \\
\hline
\end{tabular}

From table 1, the results of linearity test shows that the significance values for Linearity are smaller than 0.05 , so it can be concluded that the linearity assumption of structural models has been fulfilled.

\section{b. SmartPLS Data Analysis}

Data analysis techniques with Partial Least Square Modeling (PLS) use several important stages, they are:

1) Match Model Measurement Test (Outer Model)

\section{Validity test}

Convergent validity in the measurement model (outer model) for reflective indicators can be seen from the correlation between the score items with the score of the construct, where the indicator is considered valid if it has a loading factor more than 0.5 (Ghozali, 2014). 


\begin{tabular}{|c|c|c|c|c|}
\hline Code & $\boldsymbol{O C B}$ & $\boldsymbol{Q W L}$ & WM & WP \\
\hline OCB1 & 0,923 & - & - & - \\
\hline OCB2 & 0,894 & - & - & - \\
\hline OCB3 & 0,854 & - & - & - \\
\hline OCB4 & 0,821 & - & - & - \\
\hline OCB5 & 0,839 & - & - & - \\
\hline OCB6 & 0,903 & - & - & - \\
\hline OCB7 & 0,899 & - & - & - \\
\hline OCB8 & 0,904 & - & - & - \\
\hline QWL1 & - & 0,729 & - & - \\
\hline QWL2 & - & 0,919 & - & - \\
\hline QWL3 & - & 0,917 & - & - \\
\hline QWL4 & - & 0,724 & - & - \\
\hline QWL5 & - & 0,696 & - & - \\
\hline QWL6 & - & 0,831 & - & - \\
\hline QWL7 & - & 0,702 & - & - \\
\hline QWL8 & - & 0,891 & - & - \\
\hline WM1 & - & - & 0,925 & - \\
\hline WM 2 & - & - & 0,923 & - \\
\hline WM 3 & - & - & 0,877 & - \\
\hline WM 4 & - & - & 0,881 & - \\
\hline WM 5 & - & - & 0,888 & - \\
\hline WM 6 & - & - & 0,698 & - \\
\hline WM 7 & - & - & 0,839 & - \\
\hline WM 8 & - & - & 0,838 & - \\
\hline WP1 & - & - & - & 0,833 \\
\hline WP2 & - & - & - & 0,780 \\
\hline WP3 & - & - & - & 0,601 \\
\hline WP4 & - & - & - & 0,774 \\
\hline WP5 & - & - & - & 0,838 \\
\hline WP6 & - & - & - & 0,785 \\
\hline WP7 & - & - & - & 0,916 \\
\hline WP8 & - & - & - & 0,607 \\
\hline WP9 & - & - & - & 0,927 \\
\hline
\end{tabular}

Table 2 above shows that loading factors provide the recommended value above 0.5 , so it can be concluded that the indicators used in this study are valid or have met the requirements of Convergent Validity.

Likewise testing the validity of each construct was tested with Average Variance Exteracted (AVE) where the construct with good validity if it is more than 0.5 (Ghozali, 2014).
Here is the value of Average Variance Extracted (AVE):

\section{Table 3 Average Variance Extracted (AVE) Value}

\begin{tabular}{|c|l|c|}
\hline No & \multicolumn{1}{|c|}{ Variabel } & $\boldsymbol{A V E}$ \\
\hline 1 & $O C B$ & 0,507 \\
\hline 2 & $Q W L$ & 0,502 \\
\hline 3 & Work motivation & 0,521 \\
\hline 4 & Work performance & 0,519 \\
\hline
\end{tabular}

Table 3 above shows that the value of Average Variance Extracted (AVE) of all variables are above 0.5 which means that all latent variables (Organization Citizenship Behavior (OCB), Quality of Work Life (QWL), work motivation and work performance have met the requirements of Convergent Validity.

Validity can also be seen by comparing the value of Square root of Average Variance Extracted (AVE) for each construct with the correlation between constructs and other constructs in the model. Here is the square root value of Average Variance Extracted (AVE):

\section{Table 4}

Square Root of AVE Value

\begin{tabular}{|l|c|c|c|c|}
\hline \multicolumn{1}{|c|}{ Variables } & $\boldsymbol{O C B}$ & $\boldsymbol{Q W L}$ & $\mathbf{W M}$ & WP \\
\hline$O C B$ & $\mathbf{0 , 7 1 2}$ & & & \\
\hline$Q W L$ & 0,634 & $\mathbf{0 , 7 0 9}$ & & \\
\hline Work motivation & 0,707 & 0,491 & $\mathbf{0 , 7 2 2}$ & \\
\hline Work performance & 0,567 & 0,633 & 0,684 & $\mathbf{0 , 7 2 0}$ \\
\hline
\end{tabular}

Table 4 above shows that the square root of Average Variance Extracted (AVE) values of all latent variables Organization Citizenship Behavior (OCB), Quality of Work Life (QWL), work motivation and work performance are equal to $(\mathbf{0 . 7 1 2}, \mathbf{0 . 7 0 9}, \mathbf{0 . 7 2 2}$ and $\mathbf{0 . 7 2 0})$ higher than the correlation value between the constructs and other constructs in the model, in other words all the latent variables in this study meet the requirements of Discriminant Validity.

\section{Reliability Test}

The reliability test is done by looking at the Composite Reliability value of the indicator block that measures the construct. The result of Composite Reliability will show a satisfactory value if it is above 0.7 . Reliability test can also be strengthened by Cronbach's Alpha where the 
recommended value is above 0.6 . Reliability test results are as follows:

Table 5 Reliability Test Results

\begin{tabular}{|l|c|c|}
\hline \multicolumn{1}{|c|}{ Variables } & $\begin{array}{c}\text { Composite } \\
\text { Reliability }\end{array}$ & $\begin{array}{c}\text { Cronbach's } \\
\text { Alpha }\end{array}$ \\
\hline$O C B$ & 0,891 & 0,860 \\
\hline$Q W L$ & 0,888 & 0,853 \\
\hline Work motivation & 0,893 & 0,861 \\
\hline Work performance & 0,905 & 0,880 \\
\hline
\end{tabular}

Table 5 above shows that the Composite Reliability value of all variables is above 0.7 , so that it can be concluded that the indicators are consistent in measuring the construct. Likewise, the Cronbach'sAlpha value of all variables is above 0.6, so that all research variables have shown as a fit measurement. This means that all question items that will be used to measure variables are reliable.

\section{2) Compatibility Test of Structural Model (Inner Model)}

Testing of the structural model (inner model) is done by looking at the R-Square value of the research model, which is a goodness of fit model test.

Table 6 R-square Values

\begin{tabular}{|l|c|}
\hline \multicolumn{1}{|c|}{ Variables } & R-Square \\
\hline Work Motivation & 0,504 \\
\hline Work Performance & 0,586 \\
\hline
\end{tabular}

Table 6 above shows the R-Square value of the work motivation variable is 0.504 which means that the variability of work motivation can be explained by the construct of Organization Citizenship Behavior (OCB) and Quality of Work Life (QWL) of $50.4 \%$. Furthermore, the R-Square value of employee performance variable is 0.586 which means that employee performance variability can be explained by the construct of Organization Citizenship Behavior (OCB), Quality of Work Life (QWL) and work motivation by $58.6 \%$. The higher the R-Square value, the greater the ability of the independent variable can explain the dependent variable so that the structural equation is better.

\section{c. Hypothesis Test}

Hypothesis testing on Partial Least Square (PLS) is based on the values found in the Structural model analysis, by looking at the significance of the influence of exogenous variables Organization Citizenship Behavior (OCB), Quality of Work Life (QWL) and work motivation (WM) on work performance (WP) by looking at the parameter coefficient (path coefficient) and the significance value of t-statistics. The following is the coefficient of the parameter (path coefficient):

Table 7 Path Coefficient

\begin{tabular}{|c|l|l|l|l|}
\hline $\begin{array}{c}\text { Path } \\
\text { Coefficient }\end{array}$ & $\begin{array}{c}\text { Origina } \\
\boldsymbol{l} \\
\text { Sample }\end{array}$ & $\begin{array}{c}\text { Sampl } \\
\boldsymbol{e} \\
\text { Mean }\end{array}$ & $\begin{array}{c}\text { T- } \\
\text { statistic }\end{array}$ & $\begin{array}{c}\boldsymbol{P} \text { Value } \\
\text { Value }\end{array}$ \\
\hline$O C B \rightarrow \mathrm{WM}$ & 0,662 & 0,631 & 3,263 & 0,001 \\
\hline$Q W L \rightarrow \mathrm{WM}$ & 0,072 & 0,074 & 0,379 & 0,705 \\
\hline$O C B \rightarrow \mathrm{WP}$ & $-0,073$ & $-0,071$ & 0,441 & 0,660 \\
\hline$Q W L \rightarrow \mathrm{WP}$ & 0,419 & 0,431 & 4,982 & 0,000 \\
\hline $\mathrm{WM} \rightarrow \mathrm{WP}$ & 0,530 & 0,522 & 3,417 & 0,001 \\
\hline
\end{tabular}

Based on the results of the inner model test can be made the results of the hypothesis based on $t$ Statistic and $\mathrm{p}$-Value as shown in figure 1 as follows:

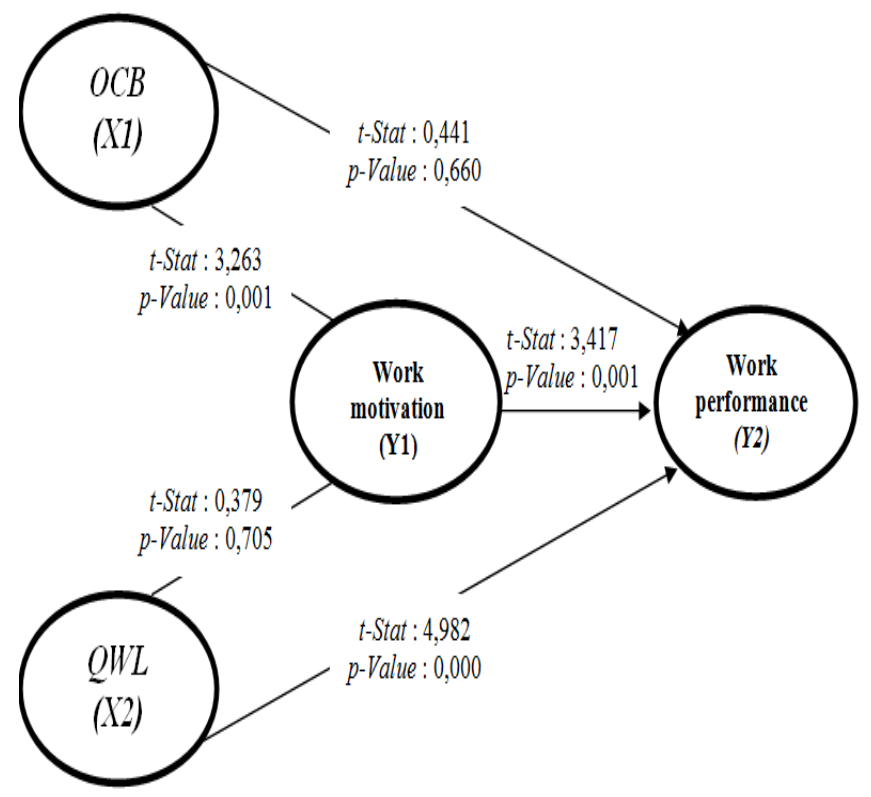

Figure 1 Hypothesis Conclusion Scheme

Based on table 7 and figure 1 above, then the results of hypothesis test can be concluded as follows:

1) The first hypothesis: Organization Citizenship Behavior (OCB) affectson work motivation, where the results of the t-statistic are 3,263 $\geq$ 1,96 or $p$-Value $0,001 \leq 0,05$, so it can be concluded that there is a significant effect of 
Organization Citizenship Behavior (OCB) on work motivation.

2) The second hypothesis: Quality of Work Life (QWL) does not affect work motivation, where the results of the t-Statistic are $0,379 \leq 1,96$ or $p$-Value $0,705 \geq 0,05$, so it can be concluded that there is no significant effect of Quality of Work Life (QWL) on work motivation.

3) Third hypothesis: Organization Citizenship Behavior (OCB) has no effect on employee work performance, where the results of the tStatistic are $0,441 \leq 1,96$ or $p$-Value $0,660 \geq$ 0,05 , so it is concluded that there is no significant effect of Organization Citizenship Behavior (OCB) on employee work performance.

4) The fourth hypothesis: Quality of Work Life (QWL) affects the performance of employees, where the results of the t-Statistic are 4,982 $\geq$ 1,96 or $p$-Value $0,000 \leq 0,05$, so it can be concluded that there is a significant effect of Quality of Work Life (QWL) on employee work performance.

5) Fifth Hypothesis: Work motivation affects employee work performance, where the tStatistic result are $3,417 \geq 1,96$ or $p$-Value $0,001 \leq 0,05$, so it can be concluded that there is a significant effect of work motivation on employee work performance.

\section{d. Intervening Variable Test Direct Effect}

Direct effect occurs if one variable affects other variables, or there is no third variable that mediates (intervening) between the two variables, where the direct effect is as follows:

\section{Table 8 Direct Effect}

\begin{tabular}{|c|c|}
\hline $\begin{array}{c}\text { Path } \\
\text { Coefficient }\end{array}$ & $\begin{array}{c}\text { Original } \\
\text { Sample }\end{array}$ \\
\hline$O C B \rightarrow \mathrm{WM}$ & 0,662 \\
\hline$Q W L \rightarrow \mathrm{WM}$ & 0,072 \\
\hline$O C B \rightarrow \mathrm{WP}$ & $-0,073$ \\
\hline$Q W L \rightarrow \mathrm{WP}$ & 0,419 \\
\hline $\mathrm{WM} \rightarrow \mathrm{WP}$ & 0,530 \\
\hline
\end{tabular}

\section{Indirect Effect}

Indirect effectoccurs if there is a third variable that mediates (intervening) between the two variables, where the indirect effect test is as follows: Table 9 Indirect Effect
Path
Nilai
Original

\begin{tabular}{|c|c|c|}
\hline Coefficient & Coefficients & Sample \\
\hline$O C B \rightarrow \mathrm{WP}$ & $0,662 \times 0,530$ & 0,351 \\
\hline$Q W L \rightarrow \mathrm{WP}$ & $0,072 \times 0,530$ & 0,038 \\
\hline
\end{tabular}

Based on the tables 8 and 9 above, the following hypotheses can be tested:

1) The Sixth hypothesis: Organization Citizenship Behavior (OCB) affects the employee work performance through work motivation as an intervening variable, where the direct effect is 0.073 and indirect effect is $0.351(0.662 \mathrm{x}$ 0.530 ), resulting in a different value between the direct effect and indirect effect with value of $-0.073<0.351$. It can be concluded that the indirect effect of work motivation variables mediate the relationship between Organization Citizenship Behavior (OCB) and employee performance. In other words, there is a significant effect of Organization Citizenship Behavior (OCB) on employee performance through work motivation as an intervening variable.

2) The seventh hypothesis: Quality of Work Life (QWL) has an effect on employee performance through work motivation as an intervening variable, from the results show that the direct effect is 0.419 and indirect effect is 0.038 $(0.072 \mathrm{x}$ 0.530), resulting in different valuesbetween direct effect and indirect effect with the value of $0.419>0.038$. It can be concluded that the indirect effect of work motivation variables cannot mediate the Quality of Work Life (QWL) to employee performance. In other words, there is no significant effect of Quality of Work Life (QWL) on employee performance through work motivation as an intervening variable.

\subsection{Discussion}

\section{a. The Effect of Organization Citizenship Behavior (OCB) on work motivation}

The results of the hypothesis test shows tStatistic value is $3,263 \geq 1,96$ or $p$-Value $0,001 \leq$ 0,05 , so it can be concluded that there is a significant effect of Organization Citizenship Behavior (OCB) on work motivation. Where the interesting dimension in this study is Altruism, with the achievement of loading factor of 0.854 and is the highest dimension in the Organization Citizenship Behavior (OCB) variable, by replacing co-workers who do not enter or break (OCB3) and willingness to be volunteer to do something without being asked $(O C B 4)$. Thus it can be said that most of the 
employees at the office of Industrial affair of South Sumatra Province have good relations with colleagues at office, which is due to the good Altruism behavior among colleagues at office.

The hypothesis results are similar to the theory from Borman and Motowidlo (2006) state that Organizational Citizenship Behavior (OCB) can improve organizational performance because this behavior is a "lubricant" of social machines in an organization. In other words, the existence of this behavior makes social interaction among employees smooth, reduces the disputes, and increases efficiency, such as being able to establish good relationships with colleagues. when the relationship was established, it will lead to motivation and morale for employees. In other words, the better the behavior of the Organization Citizenship Behavior (OCB) owned by employees in the agency, the better effect on the motivation of employees in working.

\section{b. The Effect of Quality of Work Life (QWL) on work motivation.}

From the result of hypothesis test, shows that the t-Statistic are $0,379 \leq 1,96$ or $p$-Value $0,705 \geq$ 0,05 , so it is concluded that there is no significant effect of Quality of Work Life (QWL) on work motivation. Where the results of this research hypothesis differ from the theory from Kermansaraviet.Al., (2015) that Quality of Work Life (QWL) is one of the important factors to motivate humans and increase job satisfaction within the company, it explains that Quality of Work Life (QWL) has positive impact in an effort to encourage employees to improve performance. In other words, when Quality of Work Life (QWL) is well perceived by employees, it will generate work motivation that encourages employees to further improvement for their performance to achieve optimal results.

\section{c. The Effect of Organization Citizenship Behavior (OCB) on employee performance}

From hypothesis test, the results of the tStatistic are $0,441 \leq 1,96$ or $p$-Value $0,660 \geq 0,05$, so that there is no significant influence of Organization Citizenship Behavior (OCB) on employee work performance. Where the results of this research hypothesis are different from the theory stated in Luthans (2011) that Organizational Citizenship Behavior (OCB), as a form of behavior which is an individual choice or initiative, is not related to the formal reward system but in aggregately increases the effectiveness of an organization, in other words
Organizational Citizenship Behavior (OCB) plays an important role in improving performance.

The results of this study in accordance with the results of Branham (2005) research that when the cultural values in an organization have not been well transformed, the application of behavior by all Human Resources (HR) in this institution cannot be carried out according to expectations and the emotional bond which has not been fully established. The results of this study prove that the behavior of Organizational Citizenship Behavior (OCB) of employees at the office ofindustrial affair of South Sumatra Province has not been fully implemented properly, so that it can be an obstacle to employees in working at this institution.

\section{d. The Effect of Quality of Work Life (QWL) on employee performance}

From the results of hypothesis test,the $\mathrm{t}$ Statistic are 4,982 $\geq 1,96$ or $p$-Value $0,000 \leq 0,05$, so it can be concluded that there is a significant influence of Quality of Work Life (QWL) on employee performance. Where an interesting dimension in this study is the improvement of skills and opportunities, with the achievement of loading factors of 0.936 and is the highest dimension in the variable Quality of Work Life (QWL), namely the magnitude of promotional opportunities based on work performance (QWL4), the existence of facilities and infrastructure that support employees in doing work and learning something (QWL5), as well as the magnitude of employee opportunities to develop abilities (QWL6), thus it can be said that the leaders of the office of industrial affairs of South Sumatra Province have considered the Quality of Work Life (QWL) of their employees by providing skills and opportunities to meet the expectations and needs of its employees to support the achievement and high-performance employees.

The results of this research hypothesis aresimilar to the theory according to Husnawati (2006) that there is a direct influence between Quality of Work Life (QWL) and employee performance. This is because high performance will be created if Quality of Work Life (QWL) can provide comfort and prosperity for employees in the place they work. In other words, the leader must be able to create a work atmosphere where employees feel safe and comfortable in working at the agency, so that it can have an impact on increasing the effectiveness of the employee's work. This is because employees feel that their needs are met and they feel cared for by their superiors (Jofreh et al, 2012), in other words, the better the Quality of Work 
Life (QWL), the better its impact on employee work performance.

\section{e. The Effect of work motivation on employee performance}

From the results of hypothesis test, the tStatistic are $3,417 \geq 1,96$ or $p$-Value $0,000 \leq 0,05$, so it can be concluded that there is a significant effect of work motivation on employee performance. The most significant indicator in this study is the highest mean of the work motivation variable of 3.86 that is establishing a good relationship between employees and colleagues (WM5), and the second is the opportunity to exchange ideas with colleagues (WM6). Thus it can be concluded that employees at the Office of industrial affairs of South Sumatra Province are motivated to work because of the existence of social needs, so that it can be a driving force and encouraging employees to improve their work performance in the institution.

The results of the hypothesis is in accordance with Sunyoto (2013) in his research that motivation is an encouragement aimed to Human Resources (HR) by questioning how to direct the power and potential of employees to work in accordance with company goals. In other words, the process of giving encouragement is a series of activities carried out in effort to foster the enthusiasm of employees so that they can work in line with the goals of the institution. It explains that the greater the level of motivation that employees have, the better the performance given by employees to achieve the goals of the institution.

\section{f. The effect of Organizational Citizenship Behavior (OCB) on employee performance through work motivation}

From the results of this study, shows that there are different values of direct effect and indirect effect that is the value of $-0.073<0.351$, so that it can be concluded the work motivation variable can mediate the relationship between Organizational Citizenship Behavior (OCB) end employee work performance. It meansthat the existence of work motivation owned by employees will provide encouragement and enthusiasm for the employee to work optimally in their institution. In other words, this research shows that the need for mediation of work motivation in strengthening the effect of Organization Citizenship Behavior (OCB) on employee performance by providing work motivation so employee performance can be affected

\section{g. The Effect of Quality of Work Life (QWL) on employee performance through work motivation}

From the results of this study shows that there is different value of direct effect and indirect effect that is the value of $0.419>0.038$, so it can be concluded that the indirect effect of work motivation variable cannot mediate the Quality of Work Life (QWL) to employee work performance. From the results of this study shows that good Quality of Work Life (QWL) will raise employee satisfaction in working, and will directly affecton improving employee performance in the institution. It means that the results of this study indicate there is no need to mediate work motivation on between Quality of Work Life (QWL) to employee work performance, but Quality of Work Life (QWL) can directly affect employee performance. In other words, there is no significant influence of Quality of Work Life (QWL) on employee work performance through work motivation as an intervening variable.

\section{Conclusion}

a. The t-Statistic results are $3,263 \geq 1,96$ or $p$ Value $0,001 \leq 0,05$, so it is concluded that the Organization Citizenship Behavior (OCB) has a significant effect on the work motivation of employees at the office of industrial affair of South Sumatra Province

b. The t-Statistic results are $0,379 \leq 1,96$ or $p$ Value $0,705 \geq 0,05$, so it is concluded that Quality of Work Life (QWL) does not have a significant effect on the work motivation of employees at the office of industrial affair of South Sumatra Province

c. The t-Statistic result are $0,441 \leq 1,96$ or $p$ Value $0,660 \geq 0,05$, so it is concluded that the Organization Citizenship Behavior (OCB) does not have a significant effect on the performance of employees at the office of industrial affair of South Sumatra Province

d. The t-Statistic results are 4,982 $\geq 1,96$ or $p$ Value $0,000 \leq 0,05$, so it is concluded that Quality of Work Life (QWL) has a significant effect on the performance of employees at the office of industrial affair South Sumatra Province

e. The t-Statistic result are $3,417 \geq 1,96$ or $p$ Value $0,001 \leq 0,05$, so it can be concluded that work motivation has a significant effect on the performance of employees at the office of industrial affair of South Sumatra Province 
Furthermore, the conclusion on the effect of intervening variables on work motivation are as follows:

a. The effect of Organizational Citizenship Behavior (OCB) on employee performance directly is smaller than the indirect effect with the value of $-0.073<0.351$, therefore the measurement of the effect of Organizational Citizenship Behavior (OCB) on employee performance with motivation as an intervening variable can be done. In other words, there is a significant influence of Organizational Citizenship Behavior (OCB) on employee performance through work motivation as an intervening variable the office of industrial affair of South Sumatra Province.

b. The effect of Quality of Work Life (QWL) on employee performance directly is higher than the indirect effect of $0.419>0.038$, therefore the measurement of Quality of Work Life (QWL) effects on employee work performance with motivation as an intervening variable cannot be done. In other words, there is no significant effect of Quality of Work Life (QWL) on employee performance through work motivation as an intervening variable at the office of industrial affair of South Sumatra Province.

\section{Recommendations}

Based on the conclusions in this study, the researcherrecommends, as follows: It is recommended to the leadership of the industrial affairs ofthe South Sumatra Province to improve employee work performance programs by concerning to Quality of Work Life (QWL) and work motivation because these two variables have significant effects on employee performance. Therefore, the leadership should be able to create a good Quality of Work Life (QWL) by fulfilling what the employee's needs and expectations in improving employee performance in the institution, such as by providing skills and opportunities for employees to support them in achieving highperformance both by providing promotional opportunities based on work achievement, the existence of facilities and infrastructure supporting employees in doing work and learning something, as well as the opportunity for employees to develop their capabilities.

However, it is also important to provide motivation for employees to arouse enthusiasm and employee satisfaction, so it can encourage employees to increase their work productivity, such as by maintaining good relationships among employees, the provision of promotions in form of rewards for employees by providing the environmental work condition, because environmental work conditions also affecting on the employeescomfort in working. Good work environment is satisfying for employees will improve their performance, meanwhile an inadequate work environment will reduce work motivation and reduce the performance of employees.

\section{References}

[1] Borman, W.C dan Motowildo. (1993). Expanding The Criterion Domain to Inclde Elemants of Extra-role Performance. New Jersey.

[2] Branham. (2005). Membangun Budaya Organisasi Unggul sebagai Upaya Meningkatkan Kinerja di Era Kompetitif. Jurnal Ekonomi. Vol.1.

[3] Cascio, Wayne F. (2010). Managing Human Resources. Colorado: Mc Graw-Hill.

[4] Darmawan, D.H. (2013). Prinsip-prinsip Perilaku Organisasi. Surabaya: Pena Semesta

[5] Ghozali, Imam. (2014). Structural Equation Modeling, Metode Alternatif dengan Partial Least Squares (PLS). Universitas Diponegoro. Semarang.

[6] Gunawan, Johana Susanti, Solang, Pinkan Datun, dan Kartika, Endo Wijaya. (2013). Organizational Citizenship Behavior yang Berpengaruh Pada KinerjaKaryawan Dan Kepuasan Konsumen Di Hotel Sheraton Surabaya. Jurnal Hospitality dan Manajemen Jasa. Vol.2. No.1.

[7] Hasibuan, Malayu S.P. (2012) Manajemen Sumber Daya Manusia. Bumi Aksara: Jakarta.

[8] Husnawati, Ari. (2006). Analisis Pengaruh Kulaitas Kehidupan Kerja terhadap Kinerja Karyawan dengan Komitmen dan kepuasan Kerja sebagai Intervening Variabel. Jurnal Ekonomi Pascasarjana Undip. Semarang.

[9] Jofreh, Maouchehr. (2012). Hubungan Antara Kualitas Kehidupan Kerja dengan Kinerja Staf Teknik. Jurnal Penelitian Ilmu Terapan, Teknik, dan Teknologi.4 (15): 2507-2514.

[10]Kermansaravi, F dan Fariba Yaghoubinia. (2015). Hubungan Antara Kualitas Kehidupan Kerja dan Kepuasan Kerja. Jurnal Ilmu Ekonomi. Vol.7. No.2.

[11] Kusnadi. (2003). Masalah, Kerjasama, Konflik dan Kinerja. Tanada. Malang. 
[12]Lewis, David, Kevin Brazil, Paul Kruger, Lynne Lohfeld dan Erin Tjam. (2001). Extrinsic and Intrinsic Determinants of Quality of Work Life. International Journal. Vol 14.

[13]Luthans. (2011). Perilaku Organisasi. Ahli bahasa Vivin Andhika Yuwono. Yogyakarta.

[14] Mathis dan Jackson. (2009). Manajemen Sumber Daya Mansia. Edisi Kesepuluh. Jakarta: Salemba Empat.

[15] Podsakoff, Nathan P. Blume, Brian D., dan Whiting, Steven W. (2009). Individual- And Organizational-Level Consequences of Organizational Citizenship Behavior: A MetaAnalysis. Journal of Applied Psychology. Vol. 94. No. 1.

[16] Porkiani, Masoud, et al. (2011). Relationship Between The Quality of Work Life and Employees' Aggression. Journal of American Science, Vol. 7(2).

[17] Sunyoto. (2013). Manajemen Sumber Daya Manusia. PT Indeks. Jakarta. 